\title{
Impak Prejudis dan Jarak Sosial Terhadap Komunikasi Antara Etnik di Pangsapuri Seksyen 2 Wangsa Maju, Kuala Lumpur
}

\author{
MARZUDI MD YUNUS \\ NUR YUHANIS MOHD NASIR \\ NURUL HANIZA SAMSUDIN \\ Universiti Malaya
}

\begin{abstract}
ABSTRAK
Komunikasi yang berkesan merupakan elemen penting dalam interaksi antara etnik yang berbeza. Menerusi komunikasi, interaksi sosial antara etnik dapat mengurangkan jarak sosial. Jarak sosial boleh mewujudkan rasa keasingan (alienasi) yang diasaskan oleh perbezaan ras melibatkan kelompok yang berbeza. Dalam hal ini, interaksi sosial pada peringkat komuniti setempat merupakan wadah yang boleh digunakan untuk mengetahui sama ada interaksi sosial dalam komuniti menghasilkan komunikasi yang bermakna, pengaruh prejudis dan kewujudan jarak sosial antara etnik dalam komuniti penghuni rumah jenis pangsapuri yang dikaji. Kajian ini menganalisis pola-pola interaksi sosial dalam komunikasi yang melibatkan etnik berbeza di rumah jenis pangsapuri. Penyelidikan ini dilaksanakan di Seksyen 2, Wangsa Maju, Kuala Lumpur. Metodologi kuantitatif dan kualitatif melalui kaedah soal selidik dan pemerhatian telah digunakan bagi mendapatkan data-data utama digunakan untuk menganalisis pola-pola komunikasi dalam interaksi antara etnik. Seramai 300 orang responden yang dipilih secara berstrata berdasarkan komposisi etnik di kawasan kajian. Pemerhatian pula telah dilakukan terhadap peristiwa interaksi sosial yang berlaku dalam komuniti. Dalam kajian ini, teori jarak sosial telah digunakan bagi menilai dan mentafsir pola interaksi sosial dalam komunikasi antara etnik yang berlaku dalam komuniti penduduk jenis pangsapuri. Hasil analisis telah menunjukkan bahawa terdapat pola yang jelas dalam interaksi sosial yang melibatkan komunikasi antara etnik berbeza. Komunikasi antara etnik mempunyai kaitan yang signifikan dengan kewujudan kepentingan bersama dalam kalangan penduduk. Kewujudan kepentingan bersama yang dikongsi oleh ahli komuniti akan membina pelantar integrasi yang kukuh dalam komuniti multietnik.
\end{abstract}

Kata kunci: Komunikasi, interaksi sosial, etnik, jarak sosial, komuniti.

\section{Impact of Prejudice and Social Distance on Inter-Ethnic Communication in Wangsa Maju Section 2 Apartments, Kuala Lumpur}

\begin{abstract}
Effective communication is vital in inter-ethnic interaction. Through communication, social interaction between ethnicities can reduce social distance. Social distance can create a sense of alienation based on racial differences involving different groups of people. In this case, social interaction at the local community level is a platform to find out whether social interaction in the community produces meaningful communication, the influence of prejudice and the existence of inter-ethnic social distance in the apartment occupants of the apartment type studied. This study analyzes patterns of social interaction in communication involving different ethnicities in Section 2, Wangsa Maju, Kuala Lumpur. This study used a survey and observation methods to analyze communication patterns in inter-ethnic interactions. A total
\end{abstract}


of 300 respondents were selected by stratified sampling based on ethnic composition in the study area. This study used the social distance theory to assess and interpret the pattern of social interaction in interethnic communication that occurs in apartment-type resident communities. The results of the analysis showed that there is a clear pattern in social interactions involving communication between different ethnicities. Inter-ethnic communication has a significant relationship with the existence of shared interests among the population. The existing of shared interests by community members will build a better platform of integration within the multi-ethnic community.

Keywords: Communication, social interaction, ethnic, social distance, community.

\section{PENDAHULUAN}

Di Malaysia, interaksi sosial merupakan satu cabaran dalam mewujudkan masyarakat yang bersatu padu dan membentuk perpaduan yang erat berdasarkan prinsip negara bangsa iaitu bangsa Malaysia. Hubungan antara etnik dalam konteks komunikasi sosial merupakan suatu yang amat penting sekali. Kepentingan terhadap aspek interaksi sosial dapat dilihat berdasarkan usaha-usaha yang dilakukan oleh kerajaan melalui kempen penerapan prinsip Rukun Negara, Dasar Bahasa dan Kebudayaan Kebangsaan, Dasar Ekonomi Baru, Dasar Perpaduan Nasional, sekolah Wawasan, program 'Kongsi-Raya' dan Gagasan 1Malaysia (Shamsul, 2012; Hasnah, 2009; Najib, 2010).

Perbezaan yang meliputi aspek bahasa, agama, budaya dan pemikiran yang berasaskan kepada perbezaan etnik merupakan cabaran ke arah membentuk perpaduan yang kukuh bagi negara Malaysia yang mempunyai masyarakat majmuk. Hubungan komunikasi yang baik antara semua etnik yang berbeza merupakan satu asas utama bagi mewujudkan perpaduan yang erat bersama elemen-elemen lain seperti kestabilan politik dan ekonomi (Shamsul, 2012; Rahimin et al., 2011).

Justeru, komunikasi sosial yang mempunyai pengaruh sikap prejudis, fahaman stereotaip dan tindakan berbentuk diskriminasi menghasilkan bentuk interaksi atau hubungan yang bersifat negatif dalam masyarakat. Bentuk interaksi yang bersifat negatif akhirnya mengundang kecelakaan dan kerugian yang besar terhadap nilai-nilai kemanusiaan dan negara (Abdul Rahman, 2007).

Dalam hal ini, komunikasi sosial di peringkat komuniti setempat merupakan wadah yang boleh digunakan untuk mengetahui bentuk interaksi sosial yang berlaku dalam masyarakat yang berbeza etnik. Tambahan pula, sikap prejudis, fahaman stereotaip dan tindakan diskriminasi berupaya untuk mempengaruhi bentuk interaksi sosial dalam masyarakat yang berbeza etnik dan kebudayaan. Hasil interaksi sosial pada peringkat komuniti juga boleh memperlihatkan faktorfaktor yang menyumbang kepada pembentukan sikap prejudis, fahaman stereotaip dan tindakan diskriminasi, serta memperlihatkan pola interaksi dalam masyarakat berbeza etnik. Oleh yang demikian, komunikasi sosial merupakan elemen yang penting bagi mengenal pasti tahap kesepaduan sosial dalam masyarakat berbilang etnik seperti Malaysia. 
Perbezaan amalan agama, budaya dan pendidikan juga menjadi faktor kepada pelebaran jurang perbezaan etnik di negara ini seperti mana yang dinyatakan oleh Ruslan et al. (2005) dalam buku Kenegaraan Malaysia. Setiap etnik berpegang kepada pegangan agama, budaya dan aliran pendidikan masing-masing. Etnik Melayu beragama Islam, etnik Cina menganut agama Buddha, manakala etnik India pula menganut agama Hindu. Ada juga sebahagian etnik Cina dan India yang menganut agama Kristian. Secara umumnya, mereka mengamalkan adat resam budaya yang jauh berbeza dan terlalu asing bagi setiap etnik yang ada di Tanah Melayu (Abdul Rahman, 2011). Ini berikutan asal usul mereka dari tempat yang berbeza kedudukan geografi. Aliran sistem pendidikan yang digunakan juga berbeza, dengan bahasa pengantar yang digunakan mengikut bahasa pertuturan etnik itu sendiri. Keadaan ini telah membentuk perbezaan identiti antara etnik yang sangat jelas (Abdul Rahman \& Chin, 2011). Hal ini terus berlaku sehingga ke hari ini. Perbezaan bahasa dalam berkomunikasi ini bukan sahaja menguatkan lagi sikap perkauman, tetapi juga menghalang integrasi dan pergaulan yang erat antara etnik bagi menghasilkan kesepaduan yang utuh (Ruslan et al., 2005).

Dalam aspek sosioekonomi pula, perbezaan terjadi akibat pengasingan bidang pekerjaan mengikut etnik tertentu (Ruslan et al., 2005). Perbezaan pekerjaan juga turut menghasilkan kegiatan ekonomi yang berbeza. Etnik Cina yang tinggal di bandar-bandar menjalankan aktiviti perniagaan dan perlombongan yang mendatangkan pulangan yang lumayan. Keadaan ini berbeza dengan Etnik Melayu dan India di kawasan kampung, pedalaman dan estet yang mendapat pulangan yang sedikit dan hanya sekadar cukup untuk keperluan sara diri sahaja. Kegiatan ekonomi yang berlainan ini mewujudkan jurang pendapatan yang tidak seimbang. Perkara ini ditambah pula dengan kewujudan parti-parti politik berasaskan etnik, yang memperjuangkan ekonomi dan nasib etnik yang mereka wakili sahaja. Perjuangan memperkasakan etnik sendiri sehingga melewati sempadan sensitiviti etnik lain, telah membina jurang perbezaan, menaikkan kemarahan dan kebencian serta prasangka yang tidak berasas. Sensitiviti etnik, kemarahan dan kebencian serta prasangka ini merumitkan lagi proses perpaduan dan integrasi etnik di negara ini. Perbezaan ini merupakan antara fenomena yang boleh menggugat kestabilan politik, sosial dan keselamatan negara (Shamsul, 2003; Ruslan et al., 2005).

Komunikasi antara etnik adalah satu daripada aspek penting dalam kehidupan, kerana manusia dijadikan berbangsa-bangsa dengan pelbagai kelompok etnik. Masyarakat yang pelbagai etnik, budaya serta agama merupakan ciri-ciri utama kebanyakan negara di dunia hari ini. Hanya sedikit sahaja negara yang wujud pada hari ini berasaskan etnik tunggal. Persaingan dan konflik, sama ada secara nyata atau terbuka untuk mendapat sumber yang terhad tidak dapat dielak bagi negara yang mempunyai pelbagai etnik seperti Malaysia (Mansor et al., 2006).

\section{MAKNA KOMUNIKASI SOSIAL DAN PENGUKURAN}

Manusia walau di mana sahaja mereka berada, tidak terlepas daripada melakukan komunikasi sosial dengan manusia lain dalam lingkungan sosial mereka. Ahli sosiologi Jerman, Simmel (dalam Ritzer, 2011) menjelaskan bahawa hakikat hidup bermasyarakat terdiri daripada hubungan yang mempertemukan individu dalam kegiatan bersama seperti beragama, mencari nafkah, perkahwinan, pendidikan, beriadah dan bernegara. Hubungan yang berlaku tersebut melibatkan hubungan yang bersifat sementara dan kekal. Hubungan yang berlaku dalam masyarakat wujud akibat adanya interaksi (komunikasi), iaitu suatu tindakan yang berbalas-balasan sehingga boleh 
membawa kesan positif mahupun negatif dalam masyarakat (Veeger, 1992). Sementara itu, Blumer (dalam Veeger, 1992) menjelaskan bahawa manusia bertindak dalam suatu komunikasi (interaksi) atas dasar makna yang terkandung dalam suatu konteks interaksi. Makna yang terhasil dalam komunikasi itu berasaskan kepada konteks interaksi antara seseorang dengan seseorang yang lain senantiasa berubah-ubah akibat adanya proses penaksiran makna dan kepentingan bersama dalam membina perhubungan (Massofa, 2008; Mansor, 2018). Komunikasi dalam interaksi sosial penghuni pangsapuri merupakan salah satu petunjuk bahawa terdapat tahap dan jenis hubungan antara etnik di negara ini. Komunikasi antara etnik yang berbeza budaya merupakan sesuatu yang menarik untuk diteliti kerana wujudnya perkongsian kepentingan bersama yangmerupakan cabaran bagi membina kesepaduan sosial. Apatah lagi, unsur-unsur yang berkaitan dengan persepsi antara etnik cukup menebal dalam kehidupan sosial di negara ini (Shamsul, 2012). Kajian ini bertujuan menganalisis komunikasi yang dilakukan antara penduduk di pangsapuri. Oleh itu, wujud beberapa persoalan yang perlu diperjelaskan dalam kajian ini. Adakah interaksi sosial dalam komuniti menghasilkan komunikasi yang bermakna? Adakah interaksi sosial dalam komuniti pangsapuri turut dipengaruhi pengaruh prejudis? Dan adakah wujud jarak sosial antara etnik dalam komuniti penghuni pangsapuri yang dikaji?

\section{METODOLOGI}

Bagi menjawab persoalan yang dinyatakan, penyelidikan ini menggunakan gabungan pendekatan kualitatif dan kuantitatif bagi mendapatkan data dan menyelesaikan permasalahan kajian. Pengutipan data kuantitatif menggunakan kaedah soal selidik bagi mendapatkan pola komunikasi dalam interaksi yang dikaji. Manakala kaedah kualitatif melalui pemerhatian tidak ikut serta dilakukan bagi memahami fenomena yang berlaku dalam komuniti. Pemilihan responden menggunakan kaedah Pensampelan Rawak Berstrata (Random Stratified Sampling). Ini bermakna sampel dipilih berdasarkan kumpulan homogenous berasaskan etnik. Pecahan responden terdiri daripada 92 (30.7\%) responden etnik Melayu, 163 (54.3\%) responden etnik Cina, manakala 45 (15\%) responden etnik India. Pensampelan ini dipilih kerana ciri-ciri komuniti penduduk di kawasan kajian ini melibatkan klasifikasi populasinya yang homogenous iaitu setiap kumpulan mempunyai ciri-ciri yang serupa mengikut etnik. Saiz sampel untuk setiap kumpulan etnik telah ditentukan berdasarkan peratusan populasi dan rujukan metrik sampel rawak. Berdasarkan maklumat daripada setiausaha Persatuan Penduduk Seksyen 2, Wangsa Maju, Kuala Lumpur, penduduk yang mendaftar sebagai ahli komuniti berjumlah seramai 2,000 orang. Saiz sampel untuk kajian ini ialah seramai 300 orang responden. Manakala bagi kaedah pemerhatian pula, penyelidik telah melakukan pemerhatian secara tidak ikut serta dengan membuat catatan ke atas peristiwa interaksi antara etnik yang berlaku dalam komuniti. Segala interaksi yang dilakukan dicatat dalam buku catatan pemerhatian yang disediakan.

\section{TEORI JARAK SOSIAL}

Teori yang digunakan untuk kajian ini ialah Teori Jarak Sosial yang diperkenalkan oleh Bogardus (Ritzer, 2011). Jarak Sosial ialah satu pemisahan sosial yang wujud antara individu dengan individu, kelompok dan masyarakat. Konsep Jarak Sosial digunakan untuk memperjelaskan jurang hubungan dalam suatu interaksi sosial. Bogardus merupakan orang pertama menganalisis jarak sosial berdasarkan suatu skala tertentu bagi mengukur darjah penerimaan dan keintiman 
hubungan yang mencirikan pra-sosial dan sosial secara am. Ritzer (2011) menghuraikan bahawa struktur hubungan sosial merupakan suatu analisis dalam satu kluster konsep primer dan sekunder yang terdiri daripada aspek jumlah atau ukuran kelompok, jarak relatif, jenis dan struktur sosial.

Berdasarkan kepada aspek primer yang dinyatakan itu, setiap aspek berhubung kait pula dengan beberapa aspek sekunder yang terbit bagi memperjelaskan lagi keadaan jarak sosial dalam masyarakat. Simmel (dalam Ritzer, 2011) menjelaskan, komunikasi sosial dalam masyarakat menghasilkan suatu rangkaian "geometrik sosial" yang menghasilkan jarak sosial. Unsur seperti prejudis dan stereotaip dalam aspek primer akan terbentuk semasa interaksi sosial. Aspek primer dan sekunder dalam "geometrik sosial" ini bukanlah suatu yang bersifat khusus tetapi merupakan satu rangkuman rangkaian konsep yang wujud dalam suatu masyarakat dan digunakan bagi memperjelaskan hubungan yang berlaku sehingga wujudnya suatu jarak sosial.

Teori Jarak Sosial ini menggabungkan perasaan negatif, skop fahaman dan perasaan kebimbangan (ancaman) terhadap aspek material yang selari dengan pendekatan kepentingan diri, prasangka klasik, dan fahaman stereotaip. Blumer (1992) telah mengenal pasti empat elemen penting yang mewujudkan "rasa kedudukan" kelompok. Elemen pertama ialah suatu kepercayaan tentang keunggulan kelompok sendiri (etnosentrisme). Elemen kedua ialah sudut pandang yang melihat kelompok lain sebagai asing (alienasi) dan berbeza serta menjadikannya sebagai satu stereotaip. Elemen ketiga ialah mengandaikan dan menegaskan bahawa kelompok sendiri (in-group) mempunyai segala hak ke atas sumber, status dan keistimewaan. Manakala elemen keempat pula berkait dengan sudut pandang yang melihat segala keinginan atau tuntutan yang dibuat oleh kelompok lain (out-group) difahami sebagai usaha untuk menghakis hak sedia ada kelompoknya (in-group). Elemen-elemen tersebut pada dasarnya mempunyai hubungan dengan psikologi individu, nilai budaya, aspek kepentingan diri yang bersangkutan dengan lingkungan dan proses sosial dalam masyarakat. Teori Jarak Sosial mempunyai kelebihan dalam menganalisis fenomena komunikasi sosial dalam komuniti bersifat multietnik yang mengandungi unsur prejudis dan stereotaip, serta dipengaruhi oleh persaingan, kewujudan ancaman dan kepentingan bersama dalam suatu komuniti.

\section{SOROTAN PERBINCANGAN}

Komunikasi antara etnik merupakan cabaran dalam masyarakat untuk menghasilkan kesepaduan sosial. Komunikasi antara etnik menyebabkan wujud pengaruh negatif kepada pelaku sosial. Elemen prasangka, stereotaip dan etnosentrik merupakan antara elemen yang menjadi halangan kepada komunikasi antara etnik yang berkesan dalam masyarakat mutlietnik. Komunikasi antara etnik tidak harmoni jika elemen-elemen yang dinyatakan itu tidak diurus dengan betul dalam masyarakat. Menurut Asrul (2013), terdapat dua elemen yang mampu menghasilkan suasana harmoni dalam kepelbagaian budaya untuk bersatu bagi membangun negara dengan baik. Dua elemen tersebut ialah: a) Dengan menyeragamkan dan menghilangkan perbezaan seperti budaya, agama, nilai, dan lain-lain perkara yang memungkinkan konflik; b) Menerima perbezaan, mengakui, dan menghargainya. Kewujudan sikap saling menerima, orang yang mempunyai perbezaan dapat saling melengkapi dan saling membantu. Setiap pihak dalam masyarakat diiktiraf ciri-ciri khusus mereka, bahkan turut dikembangkan. Oleh kerana itu, sangat penting 
kearifan budaya, semangat multietnik, sikap saling menerima dan menghargai nilai budaya berbeza diterima secara terbuka.

Maizatul et al. (2019) menegaskan bahawa komunikasi tidak boleh dipisahkan daripada kehidupan manusia. Komunikasi bermula daripada kelahiran seorang manusia hinggalah kepada kematiannya. Sebagai contoh, tangisan seorang bayi setelah keluar daripada rahim ibunya menunjukkan bahawa bayi itu sudah memberi isyarat lisan dan bukan lisan kepada doktor atau bidan yang menyambutnya. Begitu juga pada saat kematian seseorang, ada isyarat yang menjadi simbol komunikasi tertentu yang memberi makna bahawa hayat seseorang akan berakhir. Justeru, kaedah berkomunikasi berkesan memerlukan kemahiran komunikasi bagi membolehkan mereka berinteraksi dengan efisien. Mesej yang tidak difahami dengan jelas, akan menjejaskan pelbagai perkara dalam komunikasi manusia. Kemahiran berkomunikasi membolehkan seseorang menguasai pelbagai bentuk komunikasi seperti secara lisan dan bukan lisan, yang merangkumi tulisan, visual, isyarat, nada suara dan bahasa badan bagi memberi impak yang positif terhadap lingkungan sosial seseorang.

Komunikasi mempunyai cabaran yang tersendiri. Perbezaan budaya boleh menimbulkan konflik jika pentafsiran makna bagi suatu mesej dilakukan secara tidak tepat dengan suatu konteks budaya. Mesej yang dihantar oleh seseorang individu kepada individu lain yang berbeza budaya mungkin tidak dapat difahami dalam suatu konteks secara tepat. Akibatnya, konflik boleh tercetus sehingga menimbulkan kecurigaan antara budaya berbeza. Dalam konteks kepelbagaian budaya, sistem komunikasi sosial yang dilakukan hakikatnya diasaskan daripada nilai dan keragaman budaya masing-masing. Dengan itu, individu memperolehi pelbagai bahasa dan norma dalam komunikasi. Bahasa pada sesuatu budaya akan berbeza dengan bahasa pada budaya yang lain. Norma bahasa pada sesuatu budaya dianggap baik dan santun, tapi belum tentu baik dan santun pada norma bahasa dan budaya yang lain (Ibrahim, 2019).

Fauziah dan Bahiyah (2018) menjelaskan bahawa aspek afektif memainkan peranan penting dalam komunikasi antara inidividu, yang merujuk kepada tindakan sosial yang didominasi oleh emosi yang bersifat spontan. Perkara ini turut melibatkan cara seseorang membuat tanggapan mengenai tingkah laku manusia apabila berhubungan dengan orang lain. Gaya komunikasi ialah satu interaksi yang melibatkan pendekatan lisan atau bukan lisan seperti memberi isyarat mempunyai makna tertentu yang perlu diinterpretasi dan difahami oleh seseorang semasa proses komunikasi atau interaksi berlangsung.

Khadijah dan Maizatul (2017) menjelaskan bahawa kepentingan komunikasi tidak terhad kepada komunikasi lisan sahaja. Komunikasi bukan lisan juga penting dalam menyampaikan maklumat atau berinteraksi. Komunikasi bukan lisan merangkumi bahasa tubuh badan, rupa, memek muka atau pergerakan muka, sentuhan, tutur bahasa, pandangan dan postur badan juga mempunyai makna dalam proses komunikasi. Komunikasi bukan lisan perlu seiring dengan komunikasi lisan. Komunikasi bukan lisan boleh digunakan untuk mengukuhkan apa yang dikatakan secara lisan. Contohnya, jika kita berbincang mengenai perkara yang serius tetapi air muka kita kurang serius, maka orang sekeliling kurang percaya dengan apa yang diperkatakan. Memek muka atau air muka merupakan imej kendiri yang ditonjolkan bagi menggambarkan imej dalaman tentang diri seseorang. Perkara ini berkait rapat dengan konsep harga diri, status dan maruah. Apabila komunikasi lisan dan bukan lisan tidak seiring, maka orang akan percaya kepada komunikasi bukan lisan. Pemaparan memek muka atau air muka yang disertai dengan gerak 
badan terbit daripada hati yang ikhlas oleh seseorang yang berkomunikasi, merupakan suatu bentuk komunikasi berkesan. Kesinambungan bahasa lisan dan bukan lisan seperti memek muka atau air muka, gerak badan yang dilakukan secara spontan atau sengaja, boleh dirasai oleh penerima mesej dan seterusnya akan mencambahkan kepuasan komunikasi antara pemberi dan penerima mesej tersebut.

Proses komunikasi yang berlaku akibat perbezaan budaya yang rencam dalam masyarakat seringkali menimbulkan konflik antara etnik sejak pra-merdeka hinggalah kepada pascakemerdekaan. Konflik yang berlaku dalam masyarakat ini sebenarnya menunjukkan suatu proses penyesuaian sosial dalam masyarakat majmuk bagi mewujudkan kesepaduan sosial (Shamsul, 2012). Bagaimanapun, terdapat juga pendapat lain yang menyatakan bahawa konflik yang berlaku sebenarnya adalah akibat perbezaan kelas sosial dalam masyarakat yang dibayangi oleh aspek etnisiti yang menebal. Oleh yang demikian, segala dasar awam yang dirancang untuk melestari sosioekonomi dilihat sebagai dasar yang bersifat etnisiti (Abdul Rahman, 2018).

Azlizan dan Norlilawati (2020) menjelaskan aktiviti yang dilakukan secara bersama seperti gotong-royong, aktviti ekonomi dan pendidikan dalam masyarakat merupakan kaedah yang boleh meningkatkan komunikasi antara etnik berbeza. Di samping itu, media massa juga mempunyai peranan yang cukup penting dalam melaporkan interaksi positif dalam kalangan rakyat yang berbeza etnik di negara ini, agar peristiwa seperti 13 Mei 1969 tidak berulang.

Fenomena yang berlaku dalam lingkungan sosial yang melibatkan interaksi dalam komunikasi yang pelbagai, sama ada bersifat positif dan juga negatif merupakan penanda aras kepada kewujudan batas etnik dalam masyarakat. Perbezaan jurang tinggi-rendah batas etnik tersebut adalah berasaskan kepada kewujudan aspek kepentingan bersama yang akan dinikmati oleh pelaku sosial. Kewujudan kepentingan bersama akan merendahkan batas etnik dalam masyarakat di Malaysia (Mansor, 2018).

Dalam konteks yang lebih besar, iaitu melibatkan sistem kenegaraan, komunikasi memainkan fungsi yang sangat penting. Sesuatu kepimpinan negara dipilih oleh rakyat adalah berasaskan keberkesanan komunikasi semasa pilihan raya. Penyampaian mesej kempen menerusi media konvensional dan baharu mampu membentuk sikap dan tingkah laku pengundi dalam sesuatu pilihan raya. Penemuan daripada kajian lepas menunjukkan bahawa bilangan undian dipengaruhi oleh penilaian yang dilakukan oleh pengundi berasaskan keadaan semasa negara seperti kestabilan ekonomi, kepimpinan tertinggi parti dan isu-isu yang dekat di hati pengundi. Hal ini kerana pengundi kini mahir dan aktif dalam mencari maklumat berkaitan isuisu semasa, khususnya yang berlaku di dalam negara (Nurul et al., 2019).

\section{PROFIL KAWASAN KAJIAN}

Seksyen 2, Wangsa Maju, Kuala Lumpur merupakan salah satu bahagian di perbandaran Wangsa Maju. Keluasan Seksyen 2, Wangsa Maju ialah berukuran satu setengah kilometer persegi. Di sebelah utara Seksyen 2 bersempadan dengan Seksyen 3, di sebelah barat pula bersempadan dengan Seksyen 1, manakala di sebelah selatan bersempadan dengan Seksyen 5 dan Seksyen 4. Keseluruhan bangunan perumahan di dalam komuniti ini adalah jenis pangsapuri lima tingkat yang tidak mempunyai kemudahan lif. Terdapat sebanyak 104 buah blok unit pangsapuri di dalam komuniti ini. Kesemua blok pangsapuri ini dibahagikan kepada tujuh kelompok iaitu A, B, C, D, E, F dan G. 
Kelompok A terdiri daripada 20 unit blok pangsapuri. Kelompok B terdiri daripada sepuluh unit pangsapuri. Kelompok $\mathrm{C}$ terdiri daripada 14 unit pangsapuri. Kelompok $\mathrm{D}$ terdiri daripada 17 unit pangsapuri. Kelompok E terdiri daripada 12 unit pangsapuri. Kelompok $F$ terdiri daripada 11 unit pangsapuri dan akhir sekali adalah kelompok $\mathrm{G}$ yang mempunyai 20 unit blok pangsapuri. Pemerhatian penyelidik terhadap kemudahan pangsapuri ini mendapati bahawa tidak terdapat kemudahan saluran pembuangan sampah di bangunannya. Ini bererti, penghuni yang ingin membuang sampah terpaksa keluar daripada bangunan pangsapuri untuk membuang sampah. Proses pembuangan sampah di luar bangunan memungkinkan interaksi berlaku antara penghuni semasa mereka berselisih apabila pergi dan balik membuang sampah.

Kemudahan awam yang disediakan oleh pihak berkuasa tempatan dalam komuniti meliputi infrastruktur seperti sekolah, tadika KEMAS, bangunan perniagaan, bangunan pasar basah, parkir kenderaan, medan selera, taman permainan kanak-kanak, gelanggang permainan remaja, dewan serba guna, rumah sampah dan tong-tong sampah. Kemudahan-kemudahan ini disediakan oleh agensi kerajaan sebagai perkhidmatan kepada rakyat. Rajah 1 merupakan lakaran yang menunjukkan susunan dan susun atur perumahan dan prasarana kemudahan yang terdapat dalam komuniti.

Terdapat dua buah sekolah kerajaan dalam kawasan komuniti ini iaitu sebuah sekolah rendah kebangsaan dan satu lagi sekolah menengah kebangsaan. Pelajar-pelajar kedua-dua sekolah ini terdiri daripada pelbagai etnik seperti Melayu, Cina, India dan Singh. Kedua-dua sekolah ini disediakan oleh Kementerian Pelajaran Malaysia. Jabatan Kemajuan Masyarakat (KEMAS) juga menyediakan keperluan pendidikan pra-sekolah kepada kanak-kanak di dalam komuniti. Semasa pemerhatian dibuat, kanak-kanak yang belajar di tadika tersebut terdiri daripada etnik Melayu, Cina dan India.

Bangunan perniagaan yang ada dalam komuniti ini merangkumi bangunan kedai runcit, pasar basah, restoran, medan selera dan gerai makan. Terdapat tiga kedai runcit dalam komuniti penduduk di sini. Kedai runcit yang pertama ialah kedai runcit The Sooq yang berada di bangunan dua tingkat yang terletak di kelompok pangsapuri blok B. Pemilik kedai runcit ini beretnik Punjabi. Pelanggan kedai runcit ini adalah ahli-ahli komuniti yang terdiri daripada pelbagai etnik. Kedai runcit yang kedua ialah Pasar Mini Indah Maju yang berada di bangunan kedai dua tingkat. Bangunan yang menempatkan Pasar Mini Indah Maju berada di laluan masuk utama yang berada di antara kelompok blok $C$ dan $D$. Kedai runcit yang ketiga ialah kedai runcit tidak bernama terletak dalam bangunan pasar basah. Pemilik kedai runcit ini ialah seorang wanita etnik India. Seperti kedai runcit yang lain, pelanggan kedai runcit ini juga terdiri daripada pelbagai etnik. Terdapat dua buah restoran yang beroperasi di bangunan kekal yang dibina khusus oleh pihak berkuasa iaitu Restoran Era Maju Tomyam dan Restoran Makanan Laut Soon-Ly. Restoran Era Maju Tomyam terletak di bangunan kedai satu tingkat yang terletak di hadapan blok F1. Sementara itu Restoran Makanan Laut Soon-Ly pula terletak di deretan rumah kedai dua tingkat bersebelahan dengan kedai runcit The Sooq.

Bangunan pasar basah yang terletak di bahagian timur laut Seksyen 2, mengandungi banyak premis perniagaan. Jenis-jenis perniagaan yang ada di dalam pasar basah ialah perniagaan ikan, daging, ayam, sayuran dan lain-lain keperluan dapur. Gerai makanan, wakil insurans, kedai andaman pengantin, pakaian, alatan sembahyang Cina, kedai runcit, surat khabar dan majalah, dan rempah ratus adalah antara perniagaan yang ada di bangunan pasar basah. 
Gerai menjual makanan yang ada di bangunan ini ialah sebanyak sepuluh buah. Dua gerai diusahakan oleh peniaga Melayu, satu diusaha oleh India Muslim dan tujuh lagi oleh peniaga Cina. Gerai makanan yang diusaha oleh peniaga Melayu dan India Muslim dikunjungi oleh pelanggan pelbagai etnik, tetapi gerai makanan yang diusaha oleh peniaga Cina hanya mendapat pelanggan etnik Cina dan India sahaja. Perniagaan sayuran, daging dan ayam dijalankan oleh peniaga etnik Cina sahaja. Berikutan itu pelanggan etnik Melayu yang datang membeli barangan dapur hanya membeli sayuran sahaja. Mereka tidak membeli barangan makanan seperti ayam dan daging di pasar basah ini.

Dalam komuniti ini, terdapat 20 kawasan yang dikhaskan sebagai parkir kenderaan. Namun begitu, kawasan parkir yang disediakan itu tidak mencukupi bagi menampung jumlah di kawasan perumahan ini menyebabkan ramai penduduk meletak kenderaan masing-masing, terutama kereta di bahu-bahu jalan dan kawasan lapang lain dalam komuniti. Persaingan untuk mendapat tempat meletak kenderaan menjadi salah satu bentuk interaksi dan komunikasi dalam kalangan penduduk komuniti ini.

Selain gerai yang terdapat dalam pasar basah, terdapat sebuah lagi tapak meniaga makanan atau medan selera. Di tapak perniagaan makanan ini terdapat lima buah gerai makanan dan minuman. Salah satu gerai makanan dan minuman di medan selera ini diusahakan oleh peniaga etnik Cina. Medan selera ini menyediakan keperluan makan dan minum untuk ahli komuniti, pekerja dari Hospital Angkatan Tentera Tuanku Mizan, dan orang ramai.

Taman dan gelanggang permainan merupakan infrastruktur yang disediakan oleh pihak berkuasa tempatan untuk kegunaan riadah. Di dalam komuniti ini terdapat lapan taman permainan kanak-kanak dan gelanggang permainan remaja. Daripada lapan taman permainan yang disediakan itu, dua merupakan gelanggang badminton dan sepak takraw yang terletak di kawasan antara blok B1 dan blok G4. Satu lagi gelanggang permainan remaja ialah gelanggang bola keranjang yang terletak di blok E8. Berhadapan sekolah rendah dan menengah yang berada di dalam komuniti terdapat satu padang bola dan futsal yang sering digunakan oleh remaja. Terdapat sebuah dewan serba guna yang disediakan oleh pihak Dewan Bandaraya Kuala Lumpur untuk kegunaan penduduk. Dewan ini digunakan oleh penduduk bagi melakukan aktiviti keramaian seperti perkahwinan, mesyuarat dan beriadah.

Penduduk yang ramai dalam komuniti ini memerlukan perkhidmatan pengurusan sisa pepejal yang baik. Untuk memenuhi keperluan tersebut, pihak berkuasa tempatan iaitu Dewan Bandaraya Kuala Lumpur telah menyediakan sepuluh rumah sampah. Tong-tong sampah besar juga disediakan di setiap blok pangsapuri untuk kegunaan penduduk. Aktiviti pembersihan dan pengutipan sampah dilakukan oleh pihak yang dilantik oleh pihak berkuasa yang terdiri daripada syarikat yang dimiliki oleh penduduk.

Selain infrastruktur yang disediakan oleh pemaju dan pihak berkuasa tempatan, ada juga struktur binaan yang bersifat kekal, sementara dan mudah alih yang dibina oleh individu dalam komuniti. Antara binaan yang dimaksudkan ialah rumah ibadat, bangunan pertubuhan politik dan sosial, kedai makan dan gerai-gerai makanan. 
Impak Prejudis dan Jarak Sosial Terhadap Komunikasi Antara Etnik di Pangsapuri Seksyen 2 Wangsa Maju, Kuala Lumpur

Marzudi Md Yunus, Nur Yuhanis Mohd Nasir \& Nurul Haniza Samsudin

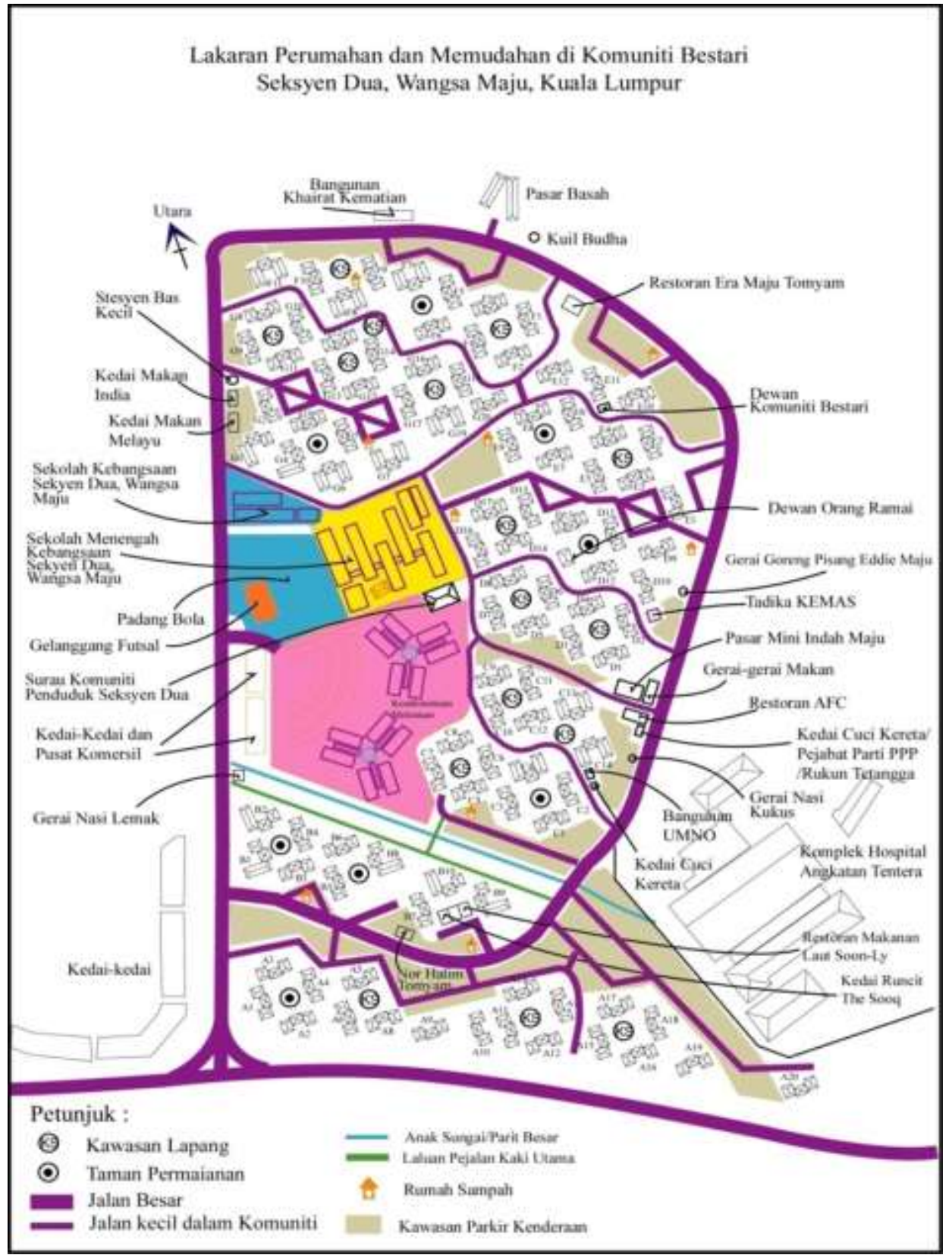

Rajah 1: Lakaran kawasan perumahan dan kemudahan yang terdapat

di Seksyen 2, Wangsa Maju

\section{ANALISIS TERHADAP KOMUNIKASI PENGHUNI}

Pola komunikasi dalam kalangan penghuni berlainan etnik dapat dikenal pasti melalui jenis-jenis komunikasi yang mereka lakukan. Dalam hal tersebut, penyelidikan ini telah menganalisis lima jenis interaksi sosial yang dilakukan bagi mengenal pasti pola komunikasi antara penghuni berlainan etnik. Jadual 1 merupakan beberapa jenis interaksi yang dilakukan oleh penghuni secara biasa dalam komuniti penduduk dengan bilangan kekerapan komunikasi yang dilakukan oleh responden. Jenis komunikasi yang pertama ialah dengan cara pandang-memandang. Interaksi jenis ini dilakukan hanya melibatkan pancaindera mata sahaja (Hashim, 2001). Dalam 
Jadual 1 tersebut, didapati bahawa mod komunikasi yang paling tinggi ialah sebanyak 3 kali, bilangan tersebut menunjukkan bahawa $28.3 \%$ responden dalam komuniti terlibat dengan jenis komunikasi dengan cara pandang-memadang.

Komunikasi yang kedua dilakukan oleh responden ialah dengan cara memberi dan membalas senyuman apabila bertemu atau bertembung semasa berjalan. Mod atau kekerapan komunikasi ialah sebanyak 2 kali sahaja, dilakukan oleh 33.7\% daripada jumlah responden yang dipilih. Komunikasi jenis ini membawa makna yang tertentu dalam interaksi sosial (Hashim, 2001). Komunikasi yang ketiga dalam Jadual 1 ialah dengan cara mengangkat tangan apabila berselisih. Hasil dapatan daripada analisis menunjukkan bahawa $55.3 \%$ responden tidak melakukan komunikasi dengan cara ini sebagai interaksi apabila berselisih. Temu bual yang dilakukan terhadap seorang informan yang merupakan peniaga, menyatakan bahawa beliau akan sentiasa menyapa sesiapa sahaja yang berselisih dengan beliau. Perkara tersebut dilakukan kerana beliau merupakan seorang peniaga yang menjalankan aktiviti perniagaan. Beliau berpendapat, seorang peniaga yang ingin berjaya mestilah mempunyai sifat ramah terhadap semua orang, sama ada yang dikenali atau pun tidak. Berbeza pula pendapat yang diberikan oleh seorang lagi informan, iaitu seorang suri rumah. Beliau mengatakan bahawa akan hanya menyapa dan memberikan senyuman kepada orang yang dikenalinya sahaja. Beliau juga sedia membalas senyuman dan sapaan apabila disapa terlebih dahulu.

Sementara itu, komunikasi yang keempat ialah bersalaman atau berjabat tangan apabila berjumpa seseorang. Hasil analisis menunjukkan bahawa majoriti, iaitu kira-kira $81.0 \%$ responden menyatakan bahawa mereka tidak melakukannya apabila berjumpa seseorang yang berlainan etnik bila berselisih. Bagaimanapun, Timbalan Pengerusi Persatuan Penduduk yang menjadi salah seorang informan menjelaskan bahawa tindakan bersalaman dengan seseorang daripada etnik lain dilakukan jika mereka saling kenal-mengenal antara satu sama lain. Amalan tersebut bukanlah dilakukan terhadap semua orang yang menghuni pangsapuri tersebut. Menurut informan ini, bersalaman hanya melibatkan individu yang saling kenal mesra antara satu sama lain sahaja. Begitu juga halnya dengan komunikasi yang dilakukan dengan cara berbual seketika apabila berjumpa dalam kawasan kejiranan. Majoriti iaitu 28.6\% responden menyatakan bahawa mereka tidak akan berbual dengan etnik lain bila berselisih dalam kawasan kejiranan.

Berdasarkan kepada dapatan yang diperolehi daripada penyelidikan ini, jelas menunjukkan bahawa komunikasi antara etnik tidak berlaku secara aktif dalam komuniti pangsapuri. Namun begitu, penelitian yang diperolehi daripada temu bual terhadap informan menunjukkan bahawa komunikasi antara etnik tetap berlaku, tetapi dilakukan berdasarkan konteks dan mempunyai makna yang tertentu. Dapatan daripada responden boleh disimpulkan sebagai dapatan secara makro atau gambaran keseluruhan terhadap komunikasi dalam komuniti pangsapuri secara am. Manakala, dapatan yang diperolehi daripada maklumat informan, ditakrifkan sebagai dapatan mikro yang mengambarkan komunikasi dalam sesuatu konteks tertentu dan mempunyai makna yang khusus. 
Impak Prejudis dan Jarak Sosial Terhadap Komunikasi Antara Etnik di Pangsapuri Seksyen 2 Wangsa Maju, Kuala Lumpur

Marzudi Md Yunus, Nur Yuhanis Mohd Nasir \& Nurul Haniza Samsudin

Jadual 1: Pola Komunikasi antara etnik (Dapatan soal selidik)

\begin{tabular}{|c|c|c|c|c|c|c|c|c|c|c|c|}
\hline \multirow[t]{2}{*}{ Jenis Komunikasi } & \multicolumn{10}{|c|}{ Kekerapan (\%) } & \multirow[t]{2}{*}{ Mod } \\
\hline & 0 & 1 & 2 & 3 & 4 & 5 & 6 & 7 & 8 & 9 & \\
\hline Pandang-memandang & 7.7 & 16.8 & 24.8 & 28.3 & 13.6 & 9.8 & 2.8 & - & 0.7 & & 3 kali \\
\hline $\begin{array}{l}\text { Memberi dan } \\
\text { membalas senyuman }\end{array}$ & 13.0 & 17.4 & 33.7 & 25.7 & 6.2 & 2.2 & 1.1 & - & 0.4 & 0.4 & 2 kali \\
\hline $\begin{array}{l}\text { Sekadar mengangkat } \\
\text { tangan }\end{array}$ & 55.3 & 13.4 & 19.5 & 7.7 & 2.4 & - & 0.8 & - & 0.4 & 0.4 & 0 \\
\hline Bersalaman bila jumpa & 81.0 & 4.8 & 8.2 & 3.5 & 1.7 & 0.4 & 0.4 & & - & - & 0 \\
\hline Berbual bila jumpa & 28.6 & 25.1 & 25.3 & 8.7 & 5.1 & 0.8 & 0.4 & & - & - & 0 \\
\hline
\end{tabular}

Bagi mengimbangi data yang diperolehi daripada soal selidik, penyelidikan ini turut melakukan pemerhatian bagi mengenal pasti komunikasi yang berlaku di persekitaran sebenar. Pemerhatian ke atas situasi sebenar dapat memberikan gambaran yang lebih jelas, di samping memahami fenomena sosial di kawasan kajian. Pemerhatian secara tidak ikut serta telah berjaya meneliti 64 peristiwa interaksi sosial yang merupakan elemen-elemen komunikasi antara etnik di pangsapuri yang dikaji. Hasil penelitian tersebut boleh dirujuk pada Jadual 2. Berdasarkan Jadual 2 tersebut, didapati sebahagian besar komunikasi yang berlaku adalah dengan cara pandang-memandang sahaja. Komunikasi yang berlaku hanya pada peringkat yang paling rendah. Lain-lain komunikasi iaitu: memberi dan membalas senyuman; mengangkat tangan, memberi isyarat tangan dan melakukan aksi badan; berjabat tangan; dan berbual seketika, bertegur sapa dan mengucap salam adalah jenis komunikasi yang berlaku dalam kadar yang rendah. Pola yang dihasilkan daripada Jadual 2 , didapati menyamai pola dapatan yang diperoleh daripada data soal selidik. Jadi boleh dirumuskan bahawa, dapatan daripada soal selidik dan pemerhatian tidak bercanggah antara satu sama lain. Oleh yang demikian, boleh disimpulkan bahawa keadaan tersebut merupakan pola komunikasi antara etnik yang berlaku di perumahan pangsapuri yang dikaji.

Jadual 2: Kaedah berkomunikasi yang dikenal pasti melalui pemerhatian di dalam komuniti.

\begin{tabular}{lcc}
\hline Cara komunikasi dilakukan & Bilangan & \% \\
\hline Pandang-memandang & 40 & 62.5 \\
$\begin{array}{l}\text { Memberi dan membalas senyuman } \\
\text { Mengangkat tangan, memberi isyarat tangan dan }\end{array}$ & 10 & 15.62 \\
$\begin{array}{l}\text { melakukan aksi badan } \\
\text { Berjabat tangan dan berpegang tangan }\end{array}$ & 7 & 10.93 \\
$\begin{array}{l}\text { Berbual, bercakap, bertegur-sapa dan mengucapkan } \\
\text { salam }\end{array}$ & 2 & 3.12 \\
\hline
\end{tabular}

Tentunya fenomena komunikasi yang berlaku memberi kesan terhadap jarak sosial antara etnik di pangsapuri tersebut. Penyelidikan ini juga turut meneliti faktor-faktor lain yang boleh memberi kesan terhadap komunikasi antara etnik di kawasan perumahan pangsapuri tersebut. Perasaan prejudis merupakan salah satu faktor yang boleh menghadkan komunikasi antara entik 
dalam sesuatu komuniti (Mansor, 2006; Shamsul, 2012). Oleh itu, ujian terhadap kewujudan sikap prejudis turut dilakukan melalui soal selidik yang telah diberikan kepada responden. Rajah 2 menunjukkan bahawa 54.0\% responden mempunyai sikap atau perasaan prejudis terhadap etnik lain. Manakala 36.3\% pula menyatakan bahawa mereka tiada sikap prejudis terhadap etnik lain. Hanya $8.3 \%$ responden didapati bersikap neutral, dan terdapat $1.3 \%$ tidak pasti akan perasaan mereka terhadap etnik berbeza.

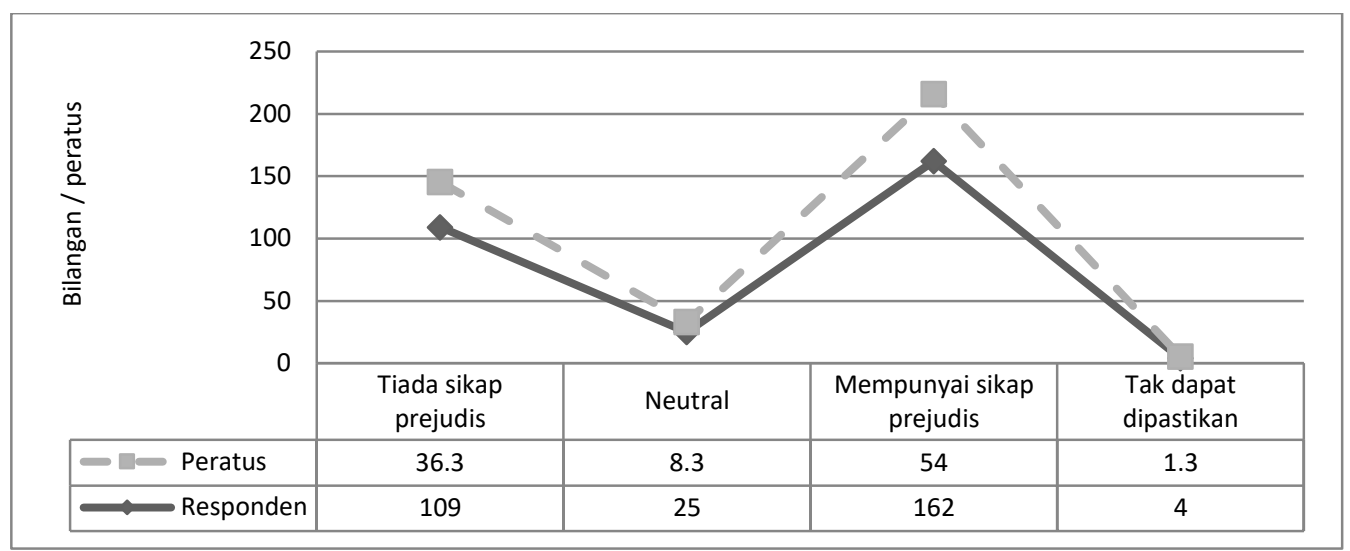

$\mathrm{N}=300$

Rajah 2 : Analisis sikap prejudis terhadap etnik berbeza

Kewujudan sikap prejudis penghuni pangsapuri adalah disebabkan kecenderungan sikap yang dikaitkan dengan prejudis. Antara perasaan yang dikaitkan dengan prejudis ialah perasaan bahawa etnik sendiri lebih baik, dan mempunyai sangkaan yang negatif terhadap etnik lain. Jadual 3 menunjukkan hasil analisis maklum balas mengikut konstruk yang menjadi gagasan sikap prejudis. Sebahagian besar responden mempunyai kecenderungan sikap yang merasakan etnik sendiri lebih baik daripada etnik lain, dan juga mempunyai sikap yang bersangka negatif terhadap etnik lain. Berdasarkan jadual tersebut, terdapat $66.7 \%$ responden mempunyai kecenderungan merasakan etnik sendiri lebih baik berbanding etnik lain dalam komuniti. Bagi konstruk sangkaan negatif pula, terdapat $48.3 \%$ responden mempunyai kecenderungan sikap bersangka negatif terhadap etnik lain. Bagaimanapun peratusan yang bersangka negatif tidaklah begitu besar jurang perbezaan berbanding peratus bilangan responden yang tiada kecenderungan bersangka negatif. Namun begitu, bagi konstruk penilaian negatif, peratusan responden yang tiada kecenderungan menilai etnik lain secara negatif, melebihi sedikit berbanding responden yang mempunyai penilaian yang negatif. Perbezaan yang sedikit itu disebabkan oleh terdapatnya peratusan yang besar bagi responden yang bersikap neutral dalam aspek menilai etnik lain. Berdasarkan temu bual terhadap informan yang merupakan peniaga pasar mini Indah Maju, perasaan tertentu seperti sangkaan negatif dan kurang mesra mungkin disebabkan kebanyakan penduduk kurang mengenali antara satu sama lain, terutamanya bagi penghuni yang tinggal di blok pangsapuri berbeza. Bagaimanapun informan ini menambah, keadaan itu tidak berlaku jika mereka saling mengenali antara satu sama lain, terutamanya bagi mereka yang tinggal di blok pangsapuri yang sama. 
Impak Prejudis dan Jarak Sosial Terhadap Komunikasi Antara Etnik di Pangsapuri Seksyen 2 Wangsa Maju, Kuala Lumpur

Marzudi Md Yunus, Nur Yuhanis Mohd Nasir \& Nurul Haniza Samsudin

Jadual 3: Maklum balas daripada konstruk-konstruk prejudis (\%)

\begin{tabular}{lcccc}
\hline Konstruk prejudis & $\begin{array}{c}\text { Tiada } \\
\text { kecenderungan } \\
\text { sikap }\end{array}$ & Neutral & $\begin{array}{c}\text { Ada kecenderungan } \\
\text { sikap }\end{array}$ & $\begin{array}{c}\text { Tak dapat } \\
\text { dipastikan }\end{array}$ \\
\hline $\begin{array}{l}\text { Perasaan etnik sendiri lebih } \\
\text { baik }\end{array}$ & 21.7 & 10.3 & 66.7 & 1.3 \\
Sangkaan negatif & 34.7 & 17 & 48.3 & - \\
Penilaian negatif & 39.7 & 26 & 34.3 & - \\
\hline
\end{tabular}

$\mathrm{N}=300$

Penyelidikan ini juga meneliti sama ada pola komunikasi antara etnik di rumah pangsapuri yang dikaji mempunyai pengaruh dengan sikap prejudis atau pun tidak. Oleh itu ujian korelasi telah dilakukan antara pembolehubah sikap prejudis dengan jenis komunikasi yang dilakukan oleh responden. Jadual 4 menunjukkan bahawa semua komunikasi yang dilakukan dipengaruhi oleh sikap prejudis terhadap etnik lain. Komunikasi secara pandang-memandang mempunyai nilai korelasi yang sangat rendah dan negatif. Nilai tersebut menunjukkan bahawa orang yang tidak mempunyai sikap prejudis lebih cenderung untuk memandang individu daripada etnik lain apabila berselisih. Komunikasi yang dilakukan secara membuat memek muka seperti memberi dan membalas senyuman, dan menggunakan tangan sebagai tanda komunikasi didapati mempunyai korelasi yang sederhana tetapi mempunyai hubungan yang signifikan dengan sikap prejudis. Sementara itu, komunikasi lain iaitu bersalaman dan berbual seketika bila berjumpa mempunyai nilai korelasi yang rendah, namun tetap mempunyai hubungan yang signifikan. Berdasarkan dapatan ini, boleh disimpulkan bahawa komunikasi bersemuka yang berlaku antara etnik di rumah jenis pangsapuri yang dikaji dipengaruhi oleh sikap prejudis.

Jadual 4: Ujian korelasi antara min komunikasi bersemuka dengan prejudis

\begin{tabular}{lcc}
\hline Korelasi komunikasi bersemuka dengan prejudis & Nilai korelasi & Keputusan \\
\hline Pandang- memandang & $-.184^{* *}$ & Signifikan pada aras korelasi .001 \\
Memberi dan membalas senyuman & $.573^{* *}$ & Signifikan pada aras korelasi .001 \\
Sekadar mengangkat tangan & $.583^{* *}$ & Signifikan pada aras korelasi .001 \\
Bersalaman bila jumpa & $.411^{* *}$ & Signifikan pada aras korelasi .001 \\
Berbual bila jumpa & $.401^{* *}$ & Signifikan pada aras korelasi .001 \\
\hline
\end{tabular}

Komunikasi yang dipengaruhi sikap prejudis telah mempengaruhi jarak sosial dalam komuniti penduduk pangsapuri yang dikaji. Kesan terhadap jarak sosial antara etnik dapat digambarkan melalui kesediaan melibatkan diri dalam aktiviti kemasyarakatan di kawasan penempatan. Jadual 5 menunjukkan penglibatan responden dalam aktiviti kemasyarakatan yang dianjurkan oleh Persatuan Penduduk Pangsapuri Seksyen 2, Wangsa Maju, Kuala Lumpur. 
Didapati $80.0 \%$ responden menyatakan bahawa mereka tidak terlibat langsung dengan aktiviti kemasyarakatan dalam komuniti penduduk. Bilangan peratusan yang terlibat dalam aktiviti sangat kecil seperti data yang ditunjukkan pada Jadual 5 . Ujian korelasi juga turut dilakukan antara pembolehubah penglibatan dalam komuniti dengan viraibel prejudis. Nilai korelasi didapati signifikan pada aras .001 dengan nilai korelasi sebanyak .321 sahaja, iaitu suatu nilai yang rendah tetapi mempunyai hubungan yang signifikan. Oleh yang demikian, boleh disimpulkan bahawa keengganan melibatkan diri dalam aktiviti komuniti menunjukkan wujudnya kecenderungan untuk tidak bercampur-gaul dalam masyarakat dengan pelbagai sebab yang tertentu.

Jadual 5: Penglibatan penghuni dalam aktiviti komuniti

\begin{tabular}{lcccccccc}
\hline $\begin{array}{l}\text { Penglibatan } \\
\text { dalam aktiviti }\end{array}$ & $\begin{array}{c}\text { R. } \\
\text { Tetangga }\end{array}$ & $\begin{array}{c}\text { AJK } \\
\text { Komuniti }\end{array}$ & RELA & Sukan & Politik & Agama & Kejiranan & $\begin{array}{c}\text { Tak } \\
\text { terlibat }\end{array}$ \\
\cline { 2 - 9 } & 2.8 & 4.3 & 1.4 & 5.7 & 1.4 & 2.9 & 1.4 & 80.0 \\
\hline
\end{tabular}

\section{PERBINCANGAN}

Secara keseluruhan, dapatan kajian menunjukkan bahawa interaksi dalam komuniti berlaku secara berpola. Ada komunikasi yang berlaku dalam erti kata mempunyai makna yang signifikan, dan ada komunikasi yang dilakukan tanpa kewujudan makna. Majoriti interaksi sosial yang berlaku dalam komuniti tidak mempunyai makna komunikasi. Interaksi sosial yang berlaku dengan cara pandang-memandang, memberi dan membalas senyuman adalah sekadar hubungan sambil lalu sahaja. Komunikasi yang dilakukan ini tidak mempunyai makna dalam konteks sebuah komunikasi yang signifikan. Komunikasi yang dilakukan ini tidak mempunyai pertukaran maklumat antara individu. Namun begitu, terdapat juga sebahagian kecil penghuni rumah pangsapuri yang melakukan komunikasi bermakna. Komunikasi secara mengangkat tangan, bersalaman dan berbual seketika apabila bertemu menunjukkan bahawa interaksi sosial yang dilakukan itu mempunyai makna dalam komunikasi. Keadaan tersebut juga menunjukkan bahawa pelaku interaksi itu saling kenal-mengenal antara satu sama lain. Interaksi yang berlaku dengan cara bersalaman juga dilanjuti dengan interaksi secara lisan telah menyebabkan wujudnya pertukaran maklumat dalam konteks sebuah komunikasi.

Berdasarkan Teori Jarak Sosial, jelas menunjukkan bahawa wujudnya suatu geometrik sosial dalam komuniti penduduk. Individu yang saling kenal-mengenal merasakan diri mereka dekat dari segi perasaan, lantas mereka akan melakukan interaksi dan komunikasi dengan lebih mesra. Kewujudan perasaan mesra akan mendekatkan fizikal mereka antara satu sama lain. Keadaan ini mewujudkan hubungan baik antara mereka yang saling kenal-mengenal. Berbeza pula keadaannya bagi individu yang tidak saling kenal-mengenal, interaksi sosial dan komunikasi dilakukan secara sambil lalu sahaja, iaitu sekadar pandang-memandang. Keadaan ini menunjukkan bahawa wujudnya jarak sosial antara mereka walaupun tinggal di suatu penempatan yang sama. Dalam konteks komuniti pangsapuri yang dikaji, elemen pengasingan tidak wujud sama sekali. Dalam konteks ini, pengasingan sosial juga tidak berlaku, mereka masih tinggal di suatu kawasan yang sama, cuma tidak sedia untuk saling berhubung atau berkomunikasi secara lebih rapat dan mesra. 
Faktor ukuran kelompok tidak begitu ketara dalam mewujudkan jarak sosial dalam komuniti yang dikaji. Walaupun populasi mengikut etnik tidak seimbang dari sudut jumlah dan peratusannya, faktor ini tidak mendatangkan kesan yang signifikan kepada jarak sosial antara penghuni berlainan etnik. Penyelidik menegaskan demikian berdasarkan beberapa aspek iaitu yang pertama ialah kedudukan rumah mengikut etnik dalam komuniti yang dikaji bersifat rawak dan tidak secara khusus di sesuatu kawasan atau blok pangsapuri. Setiap blok pangsapuri dihuni oleh ketiga-tiga etnik. Faktor ini tidak memungkinkan seseorang individu itu melakukan interaksi dan komunikasi dalam kalangan kelompok etnik mereka sahaja. Aspek kedua ialah berkaitan jaringan sosial dalam komuniti. Jaringan sosial ini melibatkan aktiviti dalam komuniti seperti jual beli, riadah, rukun tetangga walaupun aktiviti dalam komuniti itu agak rendah.

Jarak relatif dalam komuniti yang dikaji tidak menjadi suatu yang menghalang komunikasi berlaku secara aktif. Reka bentuk rumah pangsapuri yang berkoridor memberi peluang yang cukup tinggi bagi seseorang individu bertemu secara langsung secara kerap bila mereka keluar daripada rumah mereka. Oleh yang demikian, faktor jarak relatif tidak memberikan kesan yang signifikan terhadap komunikasi dan interaksi dalam komuniti rumah pangsapuri. Aspek ketiga yang dikaitkan dengan Teori Jarak Sosial ialah jenis sosial dalam komuniti. Dalam konteks kajian ini, jenis sosial boleh dikaitkan dengan hubungan sosial merentasi sempadan etnik. Dalam hubungan rentas etnik, perkara yang melibatkan sikap atau persepsi terhadap etnik lain merupakan suatu faktor yang signifikan. Elemen seperti etnosentrik menjadi faktor yang tidak boleh dipandang ringan. Etnosentrik merupakan suatu sikap dan persepsi yang menganggap bahawa budaya sendiri lebih baik daripada budaya etnik lain. Individu akan beranggapan bahawa mereka lebih superior daripada individu etnik lain (Mansor, 2006). Secara tidak langsung sikap dan persepsi ini akan menjarakkan individu berlainan etnik untuk melakukan komunikasi dengan lebih mesra. Perkara ini menjadi penghalang kepada hubungan yang bersifat mesra dan mendekatkan jarak sosial antara etnik.

Struktur sosial dalam komuniti ini boleh dikaitkan dengan konsep masyarakat Gessellschaft, iaitu melibatkan hubungan sosial yang wujud lebih khusus dan impersonal. Ini bermakna interaksi dalam kalangan anggota atau ahli bersifat individualistik dan saling tidak percaya. Hubungan sosial yang wujud adalah bersifat sekunder. Pola interaksi dalam masyarakat Gessellschaft ini terdapatnya pembahagian tugasan dan peranan yang khusus. Dalam konteks komuniti rumah pangsapuri, pembahagian tugas terdapat pada struktur sosial kepimpinan melalui persatuan penduduk yang dipilih. Ahli jawatankuasa yang dipilih mempunyai peranan yang telah ditugaskan. Ini bermakna perhubungan dalam komuniti bersifat rasmi berdasarkan kontrak dan ikatan tugas yang telah dipersetujui antara mereka. Hubungan yang bersifat peribadi berdasarkan ikatan organik tidak wujud (Ritzer, 2011).

Perbezaan-perbezaan budaya yang menerbitkan nilai-nilai berbeza telah mewujudkan jarak sosial antara individu berlainan etnik secara kolektif. Dalam hubungan melibatkan etnik, aspek yang berkaitan prejudis, stereotaip, diskriminasi dan sikap etnosentrik memberikan pengaruh yang cukup besar terhadap interaksi sosial antara etnik (Mansor, 2011). Kecenderungan sikap prejudis penghuni rumah pangsapuri ini dikaitkan dengan perasaan bahawa etnik sendiri lebih baik, dan mempunyai sangkaan negatif. Kedua-dua perasaan ini telah menjarakkan mereka untuk melakukan interaksi sosial yang membawa kepada komunikasi bermakna. Penyelidik berpendapat, perasaan bahawa etnik sendiri lebih baik telah menyebabkan 
komunikasi bermakna kurang berlaku dalam komuniti. Majoriti individu merasakan bahawa etnik mereka lebih baik dan superior berbanding etnik lain, telah menyebabkan mereka merasa budaya lain lebih rendah tarafnya. Keadaan tersebut ditambah pula dengan wujudnya sangkaan negatif terhadap etnik lain. Mereka sentiasa curiga dengan individu daripada etnik lain. Kecurigaan ini adalah berpunca daripada adanya stereotaip negatif yang diberikan terhadap suatu etnik di Malaysia. Kecurigaan ini secara tidak langsung menjarakkan individu daripada etnik berbeza untuk berkomunikasi dengan selesa. Berdasarkan kepada Jadual 4, komunikasi yang berlaku dalam komuniti yang dikaji dipengaruhi oleh sikap prejudis. Ini menunjukkan bahawa, walaupun komunikasi berlaku, sikap prejudis tetap wujud dalam diri masing-masing. Keadaan ini telah memberi kesan terhadap proses komunikasi. Pernyataan ini adalah berdasarkan kepada pandangan salah seorang informan kajian, interaksi dengan individu berlainan etnik tetap dilakukannya kerana beliau menjalankan perniagaan. Boleh dikaitkan bahawa interaksi sosial dan komunikasi dalam komuniti rumah jenis pangsapuri berlaku berasaskan kepentingan dan keperluan sosial penghuni. Kepentingan tersebut merangkumi kepentingan ekonomi dan mewujudkan suasana aman dalam komuniti, walaupan pada masa yang sama, wujud jarak sosial secara relatif antara etnik berbeza. Keadaan ini menunjukkan jarak sosial antara etnik di pangsapuri adalah bersifat dinamik berdasarkan kepentingan individu.

Fenomena yang berlaku dalam komuniti yang dikaji ini jelas menunjukkan kepelbagaian tahap batas-batas etnik dalam komuniti. Ada keadaan yang menunjukkan bahawa keadaan batas etnik yang rendah, ada yang sederhana dan ada yang tinggi. Keadaan tersebut berlaku mengikut senario kewujudan kepentingan bersama. Apabila wujud kepentingan bersama, batas etnik semakin rendah dan menipis, manakala jika tiada kepentingan bersama, maka batas etnik menjadi tinggi dan menebal (Mansor, 2018). Jika dirujuk kepada aspek infrastruktur, kemudahan dan peluang yang wujud dalam komuniti, jelas menunjukkan bahawa wujudnya kesempatan yang besar bagi penduduk yang berbeza etnik mencipta kepentingan bersama. Aspek yang paling signifikan adalah perkongsian bangunan yang sama dan kemudahan-kemudahan yang dikongsi bersama. Institusi dan infrastruktur yang ada dalam komuniti seperti institusi kemasyarakatan (persatuan penduduk), institusi ekonomi (pasar dan kedai), institusi pendidikan (KEMAS dan sekolah) dan reka bentuk bangunan itu sendiri merupakan pelantar integrasi (integration platform) yang mapan dalam mewujudkan interaksi dan komunikasi bermakna (Mansor \& Mohd Sobhi, 2019; Shamsul, 2019). Oleh yang demikian, berdasarkan data yang diperolehi, jelas menunjukkan bahawa betapa pentingnya kewujudan kepentingan bersama dalam masyarakat majmuk di Malaysia. Perkara yang melibatkan kepentingan bersama ini boleh membendung sikap prejudis dan stereotaip yang sedia wujud terus menjadi faktor penghalang kepada komunikasi aktif dan bermakna kepada masyarakat multietnik.

\section{KESIMPULAN}

Pola-pola interaksi dan jenis komunikasi menunjukkan bahawa komunikasi sambil lalu lebih dominan berlaku di rumah jenis pangsapuri. Bagaimanapun, komunikasi bermakna turut berlaku dalam komuniti melibatkan keperluan sosial individu seperti untuk tujuan perniagaan dan hubungan kejiranan. Dapatan yang diperolehi dalam penyelidikan ini menunjukkan bahawa terdapat pengaruh sikap prejudis terhadap etnik lain dalam interaksi sosial. Komunikasi antara etnik di rumah jenis pangsapuri jelas mempunyai pola tertentu berdasarkan keadaan jarak sosial 
antara mereka. Interaksi sosial antara individu yang tidak saling kenal-mengenal menghasilkan komunikasi sambil lalu yang tidak mempunyai sebarang makna. Sebaliknya bagi individu yang telah saling kenal-mengenal akan menghasilkan komunikasi yang bermakna. Individu yang saling kenal-mengenal juga akan melakukan komunikasi dalam lingkungan jarak mesra (jarak dekat), secara langsung menunjukkan jarak sosial antara mereka saling mendekati. Di samping itu juga sikap prejudis dalam kalangan penghuni rumah jenis pangsapuri yang dikaji mempengaruhi interaksi sosial sebahagian besar daripada mereka, walaupun pada masa yang sama melakukan komunikasi. Boleh disimpulkan bahawa komunikasi yang wujud antara individu berlainan etnik dilakukan berdasarkan tujuan-tujuan tertentu seperti urusan perniagaan dan sosial. Oleh yang demikian kewujudan kepentingan bersama dalam pelbagai aspek kehidupan sosial adalah sangat penting bagi menghasilkan komunikasi yang bermakna kepada masyarakat dan kesepaduan sosial.

BIODATA

Marzudi Md Yunus merupakan pensyarah kanan di Jabatan Sosio-Budaya/Kesenian Melayu, Akademi Pengajian Melayu, Universiti Malaya. Emel: marzudi@um.edu.my

Nur Yuhanis Mohd Nasir merupakan pensyarah kanan di Jabatan Sosio-Budaya/Kesenian Melayu, Akademi Pengajian Melayu, Universiti Malaya. Emel: yuhanis83@um.edu.my

Nurul Haniza Samsudin merupakan pensyarah kanan di Jabatan Bahasa Melayu, Akademi Pengajian Melayu, Universiti Malaya.Emel: haniza_85@um.edu.my 


\section{RUJUKAN}

Abdul Rahman Embong, \& Chin Yee Whah. (2011). Introduction: Community, identity, politics and healthcare in Malaysia. Jurnal Kajian Malaysia, 29(1), 1-10.

Abdul Rahman Embong. (2011). The question of culture, identity and globalisation: An unending debate. Jurnal Kajian Malaysia, 29(supp.1), 11-22.

Abdul Rahman Embong. (2018). Ethnicity and class: Divides and dissent in Malaysian studies. Southeast Asian Studies, 7(3), 281-307.

Abdul Rahman Ismail. (2007). Sejarah politik Malaysia 1965-2000. DIm. A. Rahman Ismail (pngr.). Malaysia - Sejarah kenegaraan dan politik. Kuala Lumpur: Dewan Bahasa dan Pustaka.

Asrul Muslim. (2013). Interaksi sosial dalam masyarakat multietnis. Jurnal Diskursus Islam, 1(3), 484-494.

Azlizan Mat Enh, \& Norlilawati Samak. (2020). Peranan akhbar sebagai wadah komunikasi pemerintah selepas Pilihan Raya Umum 1969. Jurnal Komunikasi: Malaysian Journal of Communication, 36(1), 1-19.

Blumer, H. (1992). Symbolic Interactionism: Perspective and method. Berkerley: University of California Press.

Fauziah Ismail, \& Bahiyah Omar. (2018). Kesan gaya komunikasi doktor perubatan terhadap kepuasan pesakit. Jurnal Komunikasi: Malaysian Journal of Communication, 34(3), 7395. https://doi.org/10.17576/JKMJC-2018-3403-05

Hashim Fauzy Yaacob. (2001). Komunikasi antara manusia. Skudai: Penerbit Universiti Teknologi Malaysia.

Hasnah Hussiin. (2009). Artikel kenegaraan dan hubungan etnik. Kuantan: Penerbit Universiti Malaysia Pahang.

Ibrahim. (2019). Konteks budaya dalam komunikasi antarabudaya (Kes pelajar IAIN Pontianak, Indonesia). Jurnal Komunikasi: Malaysian Journal of Communication, 35(2), 227-246.

Khadijah Alavi, \& Maizatul Haizan Mahbob. (2017). Komunikasi berkesan dengan warga emas: Dari perspektif intervensi kerja sosial. Jurnal Komunikasi: Malaysian Journal of Communication, 33(4), 21-37.

Maizatul Haizan Mahbob, Nik Anis Syakira Megat Ali, Wan Idros Wan Sulaiman \& Wan Amizah Wan Mahmud. (2019). Komunikasi strategik dan peranannya untuk mewujudkan komunikasi berkesan dalam organisasi. Jurnal Komunikasi: Malaysian Journal of Communication, 35(2), 49-67.

Mansor Mohd. Noor, \& Mohd Sobhi Ishak. (2019). IPNas: Model integrasi kesepaduan nasional rakyat Malaysia. Diakses dari https://www.perpaduan.gov.my/sites /default/files/Seminar\%20IPNas_Prof.\%20Dr\%20Mansor\%20dan\%20PM\%20Dr.\%20Moh d\%20Sobhi.pdf

Mansor Mohd. Noor, Abdul Rahman Abdul Aziz, \& Mohamad Ainuddin Iskandar Lee. (2006). Hubungan etnik di Malaysia. Petaling Jaya: Prentice Hall Peason Malaysia Sdn. Bhd.

Mansor Mohd. Noor. (2018). Batas etnik. Diakses dari https://mansormohdnoor.com/1-2-batasetnik/ 
Massofa. (2013). Pengertian interaksi sosial. Diakses pada 2013, Februari 15, dari http;//massofa.wordpress.com/2008/02/06/bidang-kajian-sosiologi-dan-interaksi sosial/.html

Najib Razak. (2010). Tranformasi Malaysia: Ucapan Perdana Menteri Najib Tun Razak 2009. Kuala Lumpur: Jabatan Penerangan Malaysia.

Nurul Naemah Hamedan, Syed Agil Shekh Alsagoff, \& Akmar Hayati Ahmad Ghazali. (2019). Media, isu dan tingkah laku pengundi dalam Pilihan Raya Umum ke-14: Satu kajian awal. Jurnal Komunikasi: Malaysian Journal of Communication, 35(2), 293-312.

Rahimin Affandi Abd. Rahim, Mohd Anuar Ramli, Paizah Ismail, \& Nor Hayati Mohd Dahlal. (2011). Dialog antara agama: Realiti dan prospek di Malaysia. Jurnal Kajian Malaysia, 29(2), 91-110.

Ritzer, G. (2011). Sociological theory (8th ed.) New York: The McGrow Hill Companies.

Ruslan Zainuddin, Mohd. Mahadee Ismail, \& Zaini Othman. (2005). Kenegaraan Malaysia. Shah Alam: Oxford Fajar Sdn. Bhd.

Shamsul Amri Baharuddin. (2003). Pembentukan identiti di Malaysia: Konsep, pengalaman dan masa depan. Dlm. Shamsul, Rahimah, Abdul Rahman, Mohamed Yusoff \& Kamaruddin (pnyt.), Membina bangsa Malaysia (Jilid 2, hlm. 27-55). Kuala Lumpur: Jabatan Perpaduan Negara.

Shamsul Amri Baharuddin. (2012). Modul hubungan etnik (Edisi Kedua). Bangi: Institut Kajian Etnik, Universiti Kebangsaan Malaysia.

Shamsul Amri Baharuddin. (2019). Dari kesatuan ke perpaduan IPNas sebagai pengukur. Diakses dari https://www.perpaduan.gov.my/sites/default/files/Seminar\%20 IPNas_Prof.\%20Ulung\%20Datuk\%20Dr.\%20Shamsul\%20Amri.pdf

Veeger, K. J., Hasan, D. H., Ngganggung, P. P., Widyastuty, R. A., .... Sanyotohadi, H., \& Suharto, D. J. (1992). Pengantar sosiologi: Buku panduan mahasiswa. Jakarta: Asosiasi Perguruan Tinggi Katolik dan Penerbit PT Gramedia Pustaka Utama. 